\title{
Parental involvement for better education: The relationship between parental awareness, emotional support, and children's academic achievement at secondary level
}

\author{
Keterlibatan orang tua untuk pendidikan yang lebih baik: Hubungan antara \\ kesadaran orang tua, dukungan emosional, dan prestasi akademik anak-anak di \\ tingkat menengah
}

\author{
Junaid Aman', Muhammad Babar Akram², Siti Mas'udah $^{3}$, \\ Muhammad Saud ${ }^{4}$, \& Yasir Nawaz Manj $^{5}$ \\ ${ }^{1}$ Colleges and Higher Education Department, Government of Balochistan \\ ${ }^{2}$ Department of Sociology, Faculty of Social Sciences, International Islamic University Islamabad \\ ${ }^{3,4}$ Department of Sociology, Faculty of Social and Political Science, Universitas Airlangga \\ ${ }^{5}$ Department of Sociology and Criminology, University of Sargodha \\ Address: ${ }^{1}$ Dera Murad Jamali, Nasirabad, Balochistan, Pakistan \\ ${ }^{2} \mathrm{H}-10$, Islamabad, Islamabad Capital Territory 44000, Pakistan \\ 3,4Jalan Airlangga No. 4-6, Surabaya, East Java, Indonesia 60286 \\ ${ }^{5}$ University Road, Sargodha, Punjab 40100, Pakistan \\ E-mail: ud.fisip.unair@gmail.com
}

\begin{abstract}
Students' academic achievement greatly influenced by their parents' socioeconomic status and involvement in their academic life. Regardless of the parents' educational qualifications, their support helps the children gain confidence in education and then in life. This study intends to see the relationship between two independent variables: parental awareness and emotional support to children and one dependent variable: academic achievement. The study area is Jafarabad, a district in Balochistan, Pakistan. The sample size was 250, designated using the Taro Yamani formula, and a simple random sampling technique was used to choose the respondents. The questionnaire was then used to collect information. The collected data was then coded and analysed in SPSS. Pearson correlation test was used to test the hypotheses. Significant findings show that the lack of parental awareness and interest in student's school activities is the primary cause of their poor academic achievement at secondary school. Accordingly, the study concludes that it is the primary responsibility of parents to support their children and cooperate with school administration emotionally. Therefore, the government, specifically the district education office, and local NGOs need to run awareness campaigns on the importance of parental involvement in the children's education, which will result in the children's excellent academic achievement.
\end{abstract}

Keywords: parental awareness; education; emotional support; academic achievement, secondary school

\begin{abstract}
Abstrak
Prestasi akademik siswa sangat dipengaruhi oleh status sosial ekonomi dan keterlibatan orang tua dalam kehidupan akademik mereka. Terlepas dari kualifikasi pendidikan orang tua, dukungan mereka membantu anakanak mendapatkan kepercayaan dalam pendidikan dan kemudian dalam kehidupan. Penelitian ini mengkaji hubungan antara variabel independen kesadaran orang tua dan dukungan emosional untuk anak-anak dengan variabel dependen yaitu prestasi akademik. Studi ini dilakukan di Jafarabad, Balochistan, Pakistan. Jumlah responden sebanyak 250 orang dan dipilih dengan menggunakan sampel acak sederhana. Data diperoleh dengan menggunakan wawancara terstruktur (kuesioner). Data yang dikumpulkan kemudian dikodekan dan dianalisis dalam SPSS. Uji korelasi Pearson digunakan untuk menguji hipotesis. Studi ini menemukan bahwa kurangnya kesadaran orang tua dan minat dalam kegiatan sekolah siswa adalah penyebab utama buruknya prestasi akademik mereka di sekolah menengah. Dengan demikian, penelitian ini menyimpulkan bahwa orangtua memiliki tanggung jawab utama secara emosional untuk mendukung anak-anak mereka dan bekerja sama dengan administrasi sekolah. Oleh karena itu, pemerintah, khususnya institusi pendidikan kabupaten, dan LSM lokal perlu menjalankan kampanye kesadaran tentang pentingnya keterlibatan orang tua dalam pendidikan anak-anak, yang akan meningkatkan prestasi akademik anak-anak.
\end{abstract}

Kata kunci: kesadaran orangtua; pendidikan; dukungan emosional; prestasi akademik, sekolah menengah 


\section{Introduction}

Education develops individual minds. It makes the individuals and the general population very apprehensive and conscious about existence and difficulties within the society. It further made the empty minds very vigilant and creative (American Federation of Teachers 2000). Despite all the benefits, Pakistan has to fail at the back in nationwide progress and advancement because of the frail educational framework, ever since its independence. Pakistan's population is rapidly increasing to become the sixth most populous country in the world, so improving the education sector is very important to ensure the usability of the population boom (Khalid \& Khan 2006). The population in Pakistan increased dramatically from 1951 to 2005 from 34 million to 154 million. The increase in Pakistan's population occurred between 1931 and 1941, at a staggering rate of $20.1 \%$. It is due to a significant elimination and control of the epidemic diseases which reduced mortality and increased life expectancy (Afzal \& Hussain 1974). This figure contributes to a big problem for Pakistan, though, including one of the education sectors. The number of school-age children is increasing rapidly, but the Pakistani government has not been able to cope with this surge. The impact is that illiteracy rates are still high, and there are still many school-age children, up to 10 million, who do not attend school.

The secondary education system of Pakistan could not put on the ground because of several essentials: primitive parochial and state government officials, deteriorated organisations, autocrat administrations, unstable society, and powerless majority rules system. The people themselves intentionally dismissed the idea of secondary school training, preceding the effort for constructing up the country on the premise of complementary and valuable training (Zafar 2003).

The Government of Pakistan is trying to fix the education system in the country; there are still many who criticise the policies made. Teachers in Pakistan are required to attend all multilevel teacher training. This policy does not make learning excellent and useful. It makes learning very inefficient. The same thing happens in Indonesia, in which teachers are given the training to master the learning system and an integral part of government policy (Westbrook et al. 2009). The training provided is uneven, very far from practical applications, cramming, and causes teacher educators to be isolated from subject specialisation. In addition, the condition of schools in Pakistan does not have complete facilities such as desks and cupboards for learning facilities. The secondary education system in Pakistan indicated by the training of teachers who have received a number of criticisms because the services are uneven, too theoretical, and rigid classifications to produce shortcut methods, cramming, and even cheating (Davies \& Iqbal 1997).

The condition of schooling in Balochistan has dependably been in peril, by way of low education rates and very few numbers of schools. Like many other developing countries, the situation of the education sector in Pakistan is not very encouraging. The low enrolment rates at the primary level, wide disparities between regions and gender, lack of trained teachers, deficiency of proper teaching materials and poor physical infrastructure of schools indicate the poor performance of this sector (Memon 2007, Fitriani et al. 2019). There are several reasons why the conditions of education in Pakistan are terrible. It because the level of public investment is still low. As Psacharopoulos (1994) said, investment in education can affect other fields such as increasing agricultural productivity, as in Pakistan, education has a significant influence on the function of wheat and rice production. Investment in education is directed to high schools, while secondary schools lack this. The local government noted that education spending is less than two per cent of their GNP. In addition, too many subsidies for higher education, so that many Pakistani students study abroad and do not return to their home countries. It was considered to have caused a significant loss for the country. Meanwhile, the educational conditions in Pakistan have not improved, such as the lack of incomplete teachers and laboratories.

According to the Provincial Education Commission, there are only 12,500 primary, secondary, and high schools in an area that incorporates more than 22,000 human settlements. Up to a large portion of the population has no access to schools. NEC / NEMIS data shows that children aged 5 to 9 
years do not attend school (Lynd 2007). What worsens this problem is that of those 12,500 schools, 7,000 are the ones with one teacher and one room. The future of the province's children is in danger (Baloch 2015). Hassan (1990) observed "Pakistan is unfortunately really backwards in education as in certain other spheres of intellectual activities (Haider 2008). NEC/NEMIS recorded from 2005 to 2006 , only under $50 \%$ of students studied at the primary level, $20.9 \%$ ( 7.5 million) in pre-primary, $15.4 \%$ (5.6 million) in primary school, $6.9 \%$ (2.5 million) in secondary school, $2.5 \%$ ( 0.9 million) in junior high school and 4.9\% (1.8 million) in postsecondary level. It shows that Pakistan is still far from achieving primary education. It also noted that more than $35 \%$ of children aged 5 to 9 years are not attending school. That is, there are around seven million children of that age who are not accessible to the education system. Llyoid research (2009) shows that every child has the risk of dropping out of school.

The present research focuses mainly on two different levels of factors explored through the broad review of literature that principally adds to the falling standard of education. In this context, the first level was socio-economic, and the second level was parental awareness and parental emotional support to their children. Numerous research's had been conducted on this issue; however, they limited in scope by focusing on social or political aspects. This research will be different as compared to the previous ones by explaining socio-economic factors and parental support factors affecting the progress of students in the region of Balochistan (Aman et al. 2018). This study aims to find out the relationship between parental awareness and academic achievement of students at secondary schools and also the relationship between parental emotional support and academic achievement of students at secondary schools. Khan (1999) and Zubairi (1999) reasoned that the socio-economic status of individuals is correlated unequivocally with parents' income for their children and their yearly grades.

\section{Research Method}

This study used the qualitative method. The site of the study was district Jafarabad of Balochistan Province. The targeted population of the study were parents of the enrolled students of class 10th in six secondary schools of four union councils named UC Sobdarani, UC Gandakha, UC Nushki Jadeed, and UC Shahan Palal. The total population of the enrolled students at six secondary schools was 1880. In this study, a simple random sampling technique was used to draw the sample from the total population of the study area.

A total sample of two hundred and fifty (250) respondents selected from the total population and the quantitative research design was used to determine the relationship between two independent variables: parental awareness and parental emotional support, and one dependent variable: annual percentage. Data was collected through surveys, using questionnaires enlisting questions about parental awareness of education and parental emotional support to children; - univariate and Bivariate analysis of data done in SPSS. Pearson correlation test was used to find the association between dependent and independent variables.

\section{Result and Discussion}

Table 1 shows the frequency and percentage distribution of the respondents concerning their age, gender, and marital status. The table under discussion indicates the age of respondents in completed years. Age is an essential variable in scientific research in defining the response of the respondents. The above data shows that little more than one-fourth of the respondents $(26 \%)$ were from the age group of 38-43 years, $60.8 \%$ were between $44-49$ years, and $13.2 \%$ fell in the category of $50-55$ years of age. The mean age of the respondents was 46 years, with a standard deviation of 3.76 years.

Gender is the social segregation of males and females regarding their roles in society. Pakistan has significant characteristics of traditional society where females perform domestic roles for the family and males perform roles of earning income for the family. According to Table 1, an overwhelming majority of the respondents (95.2\%) were male, and the remaining $4.8 \%$ were female. 
Table 1 explains the marital status of respondents. Marriage is the legal contract between a man and woman to establish a cooperative and beneficial social institution called the family. According to the above table, an overwhelming majority of the respondents (99.2\%) married, and the remaining $0.8 \%$ were single-parent families.

Table 1.

Distribution of the respondents according to their age, gender, and marital status

\begin{tabular}{lcc}
\hline & Age & \\
\hline Age (in years) & $\mathbf{N}$ & Results (\%) \\
\hline $38-43$ & 65 & 26 \\
$44-49$ & 152 & 60.8 \\
$50-55$ & 33 & 13.2
\end{tabular}

Total $250 \quad 100$

\begin{tabular}{|c|c|c|}
\hline \multicolumn{3}{|c|}{ Mean $=46$ years S.D. $=3.76$ years } \\
\hline Gender & $\mathbf{N}$ & Results (\%) \\
\hline Male & 238 & 95.2 \\
\hline Female & 12 & 4.8 \\
\hline Total & 250 & 100 \\
\hline Marital Status & $\mathbf{N}$ & Results (\%) \\
\hline Married & 248 & 99.2 \\
\hline Single Parents & 2 & 0.8 \\
\hline Total & 250 & 100 \\
\hline
\end{tabular}

Table 2 illustrates the frequency and percentage distribution of the respondents concerning their area of residence, monthly family income in Rupees from all sources, academic qualification, and occupation of the respondents. The above data shows that one-fourth of the respondents $(25.2 \%)$ were living in urban areas, and the rest of the three fourth of the respondents $(74.8 \%)$ were residing in rural areas. Table 2 also narrates the monthly family income of the respondents from all sources. The provision of education to children is directly related to the level of income of a person. So the respondents were asked their monthly income in Rupees. According to Table 2, most of the respondents (58\%) had their monthly income of 10.000-25.000 PKR, and 37.2\% had 25.001-40.000 PKR. While the remaining 4.8\% had their monthly income of 40.001-60.000 PKR; The mean income of the respondents was 26840,0 PKR with a standard deviation of 8190,4 PKR.

Parental education is very necessary, and it helps further their children to learn and perform well at educational institutes. Table 2 shows that little less than half of the respondents $(45.2 \%)$ were illiterate. The data also indicates that $10.8 \%$ of the respondents were first passing, $10.0 \%$ were middle passed, $14.4 \%$ were matriculate passed, $5.2 \%$ were intermediate passed which is equal to $12^{\text {th }}$ grade of schooling in international standards and remaining $14.4 \%$ were graduates. Though data collection form first and middle pass respondents were somewhat in English, therefore, the researcher translated the questionnaire into the Urdu language to get reliable and valid data from the defined respondents. The mean academic qualification of the respondents was 5.42 years, with a standard deviation of 5.47 years. Moreover, Table 2 indicates the occupation of the respondents. According to Table 2, 21.6\% of the respondents were doing government service, $4 \%$ of the respondents had private jobs, $12.4 \%$ of the respondents had their own business, $2.4 \%$ were labour, $23.6 \%$ were farmer, $33.6 \%$ were selfemployed and remaining $2.4 \%$ were housewives.

Khan (1999) and Zubairi (1999) reasoned that the socio-economic status of the individuals correlated with parents'parents' education, which affects their children's academic achievement. They further expressed that parents'parents' income influences child academic achievement. Their study supports the findings of this study which are the majority of respondents have less income and were illiterate. 
The conclusions of the study by Okpala and Smith (2001) additionally second the findings of this research as argued that the role of the financial back is one of the vital components in the academic achievement of students.

Table 2.

Distribution of the respondents according to their area, monthly family income, academic qualification, and occupation

\begin{tabular}{|c|c|c|}
\hline Area of Residence & $\mathbf{N}$ & Results (\%) \\
\hline Urban & 63 & 25.2 \\
\hline Rural & 187 & 74.8 \\
\hline Total & 250 & 100 \\
\hline Monthly family income (IDR) & $\mathbf{N}$ & Results (\%) \\
\hline $10.000-25.000$ & 145 & 58 \\
\hline $25.001-40.000$ & 93 & 37.2 \\
\hline $40.001-60.000$ & 12 & 4.8 \\
\hline Total & 250 & 100 \\
\hline \multicolumn{3}{|c|}{ Mean= 2684.0 PKR S.D=8190.4 PKR } \\
\hline Academic qualification & $\mathbf{N}$ & Results (\%) \\
\hline Literate & 113 & 45.2 \\
\hline Primary & 27 & 10.8 \\
\hline Middle & 25 & 10 \\
\hline Matriculate & 36 & 14.4 \\
\hline Intermediate & 13 & 5.2 \\
\hline Graduation & 36 & 14.4 \\
\hline Total & 250 & 100 \\
\hline \multicolumn{3}{|c|}{ Mean $=5.42$ Years S.D $=5.47$ Years } \\
\hline Occupation & $\mathbf{N}$ & Results (\%) \\
\hline Government service & 54 & 21.6 \\
\hline Private service & 10 & 4 \\
\hline Business & 31 & 12.4 \\
\hline Labour & 6 & 2.4 \\
\hline Farmer & 59 & 23.6 \\
\hline Self-employed & 84 & 33.6 \\
\hline Housewife & 6 & 2.4 \\
\hline Total & 250 & 100 \\
\hline
\end{tabular}

Table 3 describes the frequency and percentage distribution of the respondents concerning their number of male and female children going to secondary school, the name of the secondary school where the child is enrolled and the percentage secured by the children in the annual exam of $9^{\text {th }}$ class. As the questionnaire asked from the respondents, who had children in both girls and boys secondary schools, so in case of girls school they only answered their number of female children enrolled in girls' secondary school, while in case of boys' secondary school they answered several male students who were enrolled. Table 3 shows that $23.6 \%$ of male children of the respondents are not going to secondary school. The majority of the male students' one in the number of the respondents $(70 \%)$ are going to secondary school while the remaining $2.4 \%$ of the children of the respondents are two in number are going to secondary school.

Table 3 also shows the number of female children of the respondents going to secondary school. The majority of the respondents ( $72.4 \%$ ) had no female children going to school. $27.2 \%$ of the respondents 
had one female child going to secondary school, while the remaining $0.4 \%$ of the respondents had two female children going to secondary school. Table 3 also indicates the name of secondary schools in which children of the respondents enrolled. The data shows that $12.8 \%$ of the respondents had children enrolled in Govt. Boys High School M. Hassan Jamali, 8\% of the respondents had children enrolled in Govt. Girls High School Chowki Jamali, 36\% of the respondents had children enrolled in Govt. Boys High School Gandakha, 15.6\% of the respondents had children enrolled in Govt. Girls High school Gandakha, 20.4\% of the respondents had children enrolled in Govt. Boys High school Nushki Jadeed while remaining 7.2\% of the respondents had children enrolled in Govt. Boys High School Shahan Palal.

Table 3.

Distribution of the respondents according to their number of male children going to school, female children, name of school and percentage secured in last annual exam

\begin{tabular}{|c|c|c|}
\hline \multicolumn{3}{|c|}{ Male children going to secondary school } \\
\hline Category & $\mathbf{N}$ & Frequency (\%) \\
\hline No children & 59 & 23.6 \\
\hline One & 185 & 70 \\
\hline Two & 6 & 2.4 \\
\hline Total & 250 & 100 \\
\hline \multicolumn{3}{|c|}{ Female children going to school } \\
\hline Category & $\mathbf{N}$ & Frequency (\%) \\
\hline No children & 181 & 72.4 \\
\hline One & 68 & 27.2 \\
\hline Two & 1 & 4 \\
\hline Total & 250 & 100 \\
\hline \multicolumn{3}{|c|}{ Name of secondary school } \\
\hline Name & $\mathbf{N}$ & Frequency (\%) \\
\hline Govt. Boys High School M. Hassan Jamali & 32 & 12.8 \\
\hline Govt. Girls High School ChowkiJamali & 20 & 8 \\
\hline Govt. Boys High School Gandakha & 90 & 36 \\
\hline Govt. Girls High school Gandakha & 39 & 15.6 \\
\hline Govt. Boys High school NushkiJadeed & 51 & 20.4 \\
\hline Govt. Boys High School ShahanPalal & 18 & 7.2 \\
\hline Total & 250 & 100 \\
\hline \multicolumn{3}{|c|}{ Child percentage secured in the last annual exam of $9^{\text {th }}$ class } \\
\hline Category & $\mathbf{N}$ & Frequency (\%) \\
\hline Up to $50 \%$ & 60 & 24 \\
\hline $50.1 \%$ to $70 \%$ & 173 & 69.2 \\
\hline Above $70.1 \%$ & 17 & 6.8 \\
\hline Total & 250 & 100 \\
\hline
\end{tabular}

Source: Primary Data

Table 4 demonstrates the percentage of a child of the respondents secured in annual exams of 9th class. It indicates that $24 \%$ of the respondents' children secured up to $50 \%$ in the annual exam, The majority of the respondents $(69.2 \%)$ children secured $50.1 \%$ to $70 \%$ while the remaining $6.8 \%$ of the respondent's children secured above $70 \%$ marks in the annual exam of $9^{\text {th }}$ class.

Table 4 describes the variables of parental awareness which asked respondents in the questionnaire. The data indicates that the majority of the respondents $(86.4 \%, 40 \% \& 46.4 \%)$ agreed to the statement that "Low educational background of parents affects the academic achievement of children". Few 
of the respondents $(6.4 \%)$ showed their neutrality regarding this notion. Those respondents who disagreed with this opinion constitute $7.2 \%, 4.4 \%$, and $2.8 \%$. The mean of the notion was 4.16 , with a standard deviation of 0.93 . Table 4 narrates that the majority of the respondents $(87.6 \%, 42 \%$, and $45.6 \%$ ) agreed to the statement that "Lack of knowledge about future career plans affects the academic achievement of children". Few of the respondents (4.8\%) showed their neutrality regarding this notion. Those respondents who disagreed with this opinion constitute $7.6 \%, 4.4 \% \& 3.2 \%$. The mean of the notion was 4.19 , with a standard deviation of 0.94 .

Table 4.

Distribution of the respondents by their degree of agreement about parental awareness

\begin{tabular}{lccccccc}
\hline \multicolumn{1}{c}{ Parental awareness F (\%) } & SA & A & N & D & SDA & Mean & S.D \\
\hline Low educational background of parents & 100 & 116 & 6 & 11 & 7 & \multirow{2}{*}{4.16} & 0.93 \\
effects academic achievement of children & $(40)$ & $(46.4)$ & $(6.4)$ & $(4.4)$ & $(2.8)$ & & \\
$\begin{array}{l}\text { Lack of knowledge about future career } \\
\text { plans affects the academic achievement of }\end{array}$ & 105 & 114 & 12 & 11 & 8 & & \\
children & $(42)$ & $(45.6)$ & $(4.8)$ & $(4.4)$ & $(3.2)$ & 4.19 & 0.94 \\
$\begin{array}{l}\text { Lack of knowledge about the importance } \\
\text { of education affects the academic }\end{array}$ & 80 & 128 & 18 & 11 & 13 & & \\
$\begin{array}{l}\text { achievement of children } \\
\text { Lack of parental teaching meetings affects }\end{array}$ & $(32)$ & $(51.2)$ & $(7.2)$ & $(4.4)$ & $(5.2)$ & 4 & 1 \\
the academic achievement of children & $(24.4)$ & $(49.2)$ & $(12)$ & $(7.2)$ & $(7.2)$ & 3.76 & 1 \\
\hline
\end{tabular}

Source: Primary Data

Notes:

$\begin{array}{ll}\text { SA } & \text { : Strongly Agree } \\ \text { A } & : \text { Agree } \\ \text { N } & : \text { Neutral } \\ \text { DA } & : \text { Disagree } \\ \text { SDA } & \text { : Strongly Disagree }\end{array}$

Table 4 reveals that the majority of the respondents $(83.2 \%, 32 \%$, and $51.2 \%)$ agreed to the statement that "Lack of knowledge about the importance of education affects the academic achievement of children". Few of the respondents (7.2\%) showed their neutrality regarding this notion. Those respondents who disagreed with this opinion constitute $9.6 \%, 4.4 \%$, and $5.2 \%$. The mean of notion was four with standard deviation 1 . The data also shows that the majority of the respondents $(73.6 \%$, $24.4 \% \& 49.2 \%$ ) strongly agreed to the statement that "Lack of parental teaching meetings affects the academic achievement of children". $12 \%$ of the respondents showed their neutrality regarding this notion. Those respondents who disagreed with this opinion constitute $14.4 \%, 7.2 \%$, and $7.2 \%$. The mean of notion was 3.76 with standard deviation 1 .

Literate parents are capable of providing such an environment that is helpful in the success of students in their studies. Similarly, the teachers at a school can guide and motivate families for creating a friendly atmosphere at home for improvement in a student's annual grades. Parental education affects their educational practices at home; parents with higher education use a variety of languages and predict great achievements for their children (Eccles 2005).

Table 5 explains the variables of parental emotional support which asked from respondents in the questionnaire. The data indicates that the majority of the respondents $(78.4 \%, 23.2 \%$, and $55.2 \%)$ were agreed respectively to the statement that "Less parental help of children in their educational problems affects their academic achievement". Few of the respondents (8\%) showed their neutrality regarding this notion. Those respondents who disagreed with this opinion constitute $14.8 \%, 12.8 \%$, and $2 \%$. The mean of notion was 3.86 with a standard deviation of 0.97 . Table 5 that little less than two-thirds of the respondents $(63.6 \%, 10.4 \%$, and 53.2\%) agreed to the statement that "Low parental rewards affect students' academic achievement". $21.6 \%$ of the respondents showed their neutrality regarding this notion. Those respondents who disagreed with this opinion constitute $14.8 \%, 12.8 \%$, and $2 \%$. 
The mean of notion was 3.57 with a standard deviation of 0.91 . Table 5 reveals that the majority of the respondents $(84.4 \%, 36 \%$, and $48.4 \%)$ agreed to the statement that "Low encouragement about the importance of education affects children academic achievement". Few of the respondents $(3.2 \%)$ showed their neutrality regarding this notion. Those respondents who disagreed with this opinion constitute $12.4 \%, 5.6 \%$, and $6.8 \%$. The mean of the notion was 4.01 , with a standard deviation of 1.1 .

Table 5.

Distribution of the respondents by their degree of agreement about parental emotional support

\begin{tabular}{|c|c|c|c|c|c|c|c|}
\hline Parental emotional support F (\%) & SA & A & $\mathbf{N}$ & D & SDA & Mean & S.D \\
\hline $\begin{array}{l}\text { Less parental help of children in the effects } \\
\text { of their educational problem their academic } \\
\text { achievement }\end{array}$ & $\begin{array}{c}58 \\
(23.2)\end{array}$ & $\begin{array}{c}138 \\
(55.2)\end{array}$ & $\begin{array}{l}20 \\
(8)\end{array}$ & $\begin{array}{c}28 \\
(11.2)\end{array}$ & $\begin{array}{c}6 \\
(2.4)\end{array}$ & 3.86 & 0.97 \\
\hline $\begin{array}{l}\text { Low parental rewards effects students' } \\
\text { academic achievement }\end{array}$ & $\begin{array}{c}26 \\
(10.4)\end{array}$ & $\begin{array}{c}133 \\
(53.2)\end{array}$ & $\begin{array}{c}54 \\
(21.6)\end{array}$ & $\begin{array}{c}32 \\
(12.8)\end{array}$ & $\begin{array}{c}5 \\
(2)\end{array}$ & 3.57 & 0.91 \\
\hline $\begin{array}{l}\text { Low encouragement about importance } \\
\text { of education effects children academic } \\
\text { achievement }\end{array}$ & $\begin{array}{c}90 \\
(36)\end{array}$ & $\begin{array}{c}121 \\
(48.4)\end{array}$ & $\begin{array}{c}8 \\
(3.2)\end{array}$ & $\begin{array}{c}14 \\
(5.6)\end{array}$ & $\begin{array}{c}17 \\
(6.8)\end{array}$ & 4.01 & 1.1 \\
\hline $\begin{array}{l}\text { Low parental monitoring of children's class } \\
\text { work affects their academic achievement }\end{array}$ & $\begin{array}{c}87 \\
(34.8)\end{array}$ & $\begin{array}{l}120 \\
(48)\end{array}$ & $\begin{array}{c}19 \\
(7.6)\end{array}$ & $\begin{array}{c}17 \\
(6.8)\end{array}$ & $\begin{array}{c}7 \\
(2.8)\end{array}$ & 4.05 & 0.97 \\
\hline $\begin{array}{l}\text { Less provision of entertainment facilities } \\
\text { at home affects children's academic } \\
\text { achievement }\end{array}$ & $\begin{array}{c}81 \\
(32.4)\end{array}$ & $\begin{array}{c}73 \\
(29.2)\end{array}$ & $\begin{array}{c}28 \\
(11.2)\end{array}$ & $\begin{array}{c}63 \\
(25.2)\end{array}$ & $\begin{array}{c}5 \\
(2)\end{array}$ & 3.65 & 1.22 \\
\hline $\begin{array}{l}\text { Less participation of parents in school } \\
\text { activities effects children academic } \\
\text { achievement }\end{array}$ & $\begin{array}{c}74 \\
(29.6)\end{array}$ & $\begin{array}{c}83 \\
(33.2)\end{array}$ & $\begin{array}{c}30 \\
(12)\end{array}$ & $\begin{array}{c}56 \\
(22.4)\end{array}$ & $\begin{array}{c}7 \\
(2.8)\end{array}$ & 3.64 & 1.20 \\
\hline
\end{tabular}

Source: Primary Data

Notes:

$\begin{array}{ll}\text { SA } & \text { : Strongly Agree } \\ \text { A } & : \text { Agree } \\ \text { N } & : \text { Neutral } \\ \text { DA } & \text { : Disagree } \\ \text { SDA } & \text { : Strongly Disagree }\end{array}$

Table 5 also describes that the majority of the respondents $(86.8 \%, 38.8 \%$, and $48.0 \%)$ agreed to the statement that "Low parental monitoring of children's class work affects their academic achievement". Few of the respondents $(7.6 \%)$ showed their neutrality regarding this notion. Those respondents who disagreed with this opinion constitute $9.7 \%, 6.8 \%$, and $2.9 \%$. The mean of notion was 4.05 with a standard deviation of 0.97 . Table 5 explains that most of the respondents $(61.42 \%, 32.4 \%$, and $29.02 \%$ ) agreed to the statement that "Less provision of entertainment facilities at home affects children's academic achievement". $11.2 \%$ of the respondents showed their neutrality regarding this notion. Those respondents who were disagreed with this opinion constitute $27.2 \%, 25.2 \% \& 2.0 \%$. The mean of notion was 3.65 with a standard deviation of 1.22.

The data further narrates that most of the respondents $(62.8 \%, 29.6 \%$, and $33.2 \%)$ agreed to the statement that "Less participation of parents in school activities affects children's academic achievement". $12 \%$ of the respondents showed their neutrality regarding this notion. Those respondents who disagreed with this opinion constitute $25 \%, 22.2 \%$, and $2.8 \%$. The mean of notion was 3.64 with a standard deviation of 1.20. Marzano (2003) inferred that the environment at home influences the learning ability of students. This concept reinforced by the study of Edmonds (1979) that the quality of teaching also supported by the involvement and support of parents and recognition of students' academic success in school (Wang 1990). The evolution of learning in schools lies not only in the role of parents and school involvement but also with an adaptive learning model where learning is designed to maximise the chances of student success. It also includes adequate time or appropriate time allocation, classroom management systems, interactions based on student needs, flexible administration, and organisational patterns that are responsive to the needs of the implementation and staffing programs. 


\section{Relationship between parental awareness and percentage of children secured in an annual exam}

Null hypothesis: There is a direct relationship between parental awareness and the percentage of children secured in an annual exam. Alternate hypothesis: There is an inverse relationship between parental awareness and the percentage of children secured in an annual exam. Table 6 describes the Pearson correlation between parental awareness and the percentage of children secured in the last annual exam had a significant positive correlation $\left(\mathrm{r}=.315^{* *} \mathrm{p}<0.001\right)$. These statistics suggest that parental awareness was directly related to the percentage of children secured in the annual exam. By implication, parental awareness was likely to have a corresponding effect on the percentage of children secured in the last annual exams and the reverse is also true. Furthermore, there will be a higher percentage of children in annual exams whenever the parents are aware of.

Table 6.

Relationship between parental awareness and percentage of children secured in an annual exam

\begin{tabular}{ccc}
\hline Independent variable & $\begin{array}{c}\text { Percentage of children secured in } \\
\text { the last annual exam }\end{array}$ \\
\hline \multirow{2}{*}{ Parental awareness } & Pearson correlation & $.315^{* *}$ \\
& $N$ & 250 \\
\hline \multicolumn{2}{c}{${ }^{*} P<.01=, P<.001=^{* *}, P<.0001=^{* * *}$} \\
\hline \multicolumn{2}{c}{ Source: Primary Data }
\end{tabular}

\section{Relationship between parental emotional support and the percentage of children secured in an annual exam}

Null hypothesis: There is a relationship between parental emotional support and the percentage of children secured in an annual exam. Alternate hypothesis: There is no relationship between parental emotional support and the percentage of children secured in an annual exam. Table 7 data shows that the Pearson correlation between parental emotional support and the percentage of children secured in the last annual exam had a significant positive correlation $\left(\mathrm{r}=.257^{* *} \mathrm{p}<0.001\right)$. These statistics suggest that parental emotional support was related to the percentage of children secured in the annual exam. By implication, parental emotional support was likely to have a corresponding effect on the percentage of children secured in the last annual exams. Furthermore, there will be a higher percentage of children in annual exams whenever there is more parental emotional support.

Table 7.

Relationship between parental emotional support and the percentage of children secured in an annual exam

\begin{tabular}{ccc}
\hline Independent variable & $\begin{array}{c}\text { Percentage of children secured } \\
\text { in the last annual exam }\end{array}$ \\
\hline $\begin{array}{c}\text { Parental emotional } \\
\text { support }\end{array}$ & Pearson correlation & $.257^{* *}$ \\
$\mathrm{~N}$ & 250 \\
\hline \multicolumn{2}{c}{${ }^{*}<<.01=, P<.001=^{* *}, P<.0001=^{* * *}$} \\
\hline \multicolumn{2}{c}{ Source: Primary Data }
\end{tabular}

Repetti (1996) revealed that the children likewise look for emotional from guardians when they confront some academic problems at school. Students from low-income families or with parents who do not have a bachelor's degree are more likely to drop out of school or college (Titus 2006). Carnevale and Rose in Titus (2006) state that dropout rates are more experienced by students from lower socioeconomic status classes because of their low enrollment in selective institutions. Therefore, the problem that is the cause is none other than financial problems.

Educated and responsible parents dependably empower their children and give proper assistance in academic difficulties, yet uneducated, and financially underprivileged parents may act aggressively and subsequently saddened their children more. In the phenomenon of low-income parents in urban 
America, parents like this described as having little contribution to the education of their children; they also cannot attend meetings, conferences, games or school activities because of difficulties in transportation (Trotman 2014). The ability of children in school is also caused by the condition of parents as experienced by urban parents. They face problems such as divorce or unmarried parents. Lippman et al. (1996) note that urban low-income children live in an increasing number of single parents headed by women. As a result, many teachers believe that low-income parents do not have a contribution to the education of their children (Davies 1988). However, this opinion is not entirely correct. Urban parents are just as interested in the education of their children as parents of any class. Unfortunately, urban parents alienated from their children's educational process. In addition, some teachers believe that poverty causes deficiencies in gaining academic skills and many poor students face adverse conditions which ultimately reduce their self-esteem taps cannot internalise ideas that they cannot achieve.

Scholars have found that students from low SES (social-economic status) backgrounds have lower educational aspirations, persistence rates, and educational attainment than their peers from high SES backgrounds prior to and during college (Walpole 2003, Astin 1993, DiMaggio \& Mohr 1985, Lareau 1993, McDonough 1997, MacLeod 1987, Pascarella \& Terenzini 1991, Tinto 1987, Tinto 1993). Social class is indeed unavoidable, including in the educational environment. Families with high socioeconomic status have a significant influence on children's education. The success of children's educational shaped by parents' style, interaction, school structure, school experience, and school fees. High socioeconomic status encourages parents to provide further attention to children in terms of quality education. It is inseparable from the involvement of parents who contribute to the achievement of their children even parents' education is also taken into account, that is, the prosperity of parents consistently correlates with educational outcomes (Eagle 1989). Whereas parents with lower economic status view diplomas as norms and define safe full-time work after graduating from high school. In addition, children from low socioeconomic status backgrounds enrolled in educational institutions with low stratification compared to families with high socioeconomic status.

The conclusions of the study directed by Okpala \& Smith (2001) additionally second the argument of the role of socioeconomic status in academic success. Some studies show that children from low SES families are more likely to show a pattern of low literacy rates; also low education participation, problematic behaviour in schools, having learning difficulties, and having a school transition to the labour market are less successful (Considine \& Zappala 2002).

Krashen (2005) reasoned that students, whose guardians are knowledgeable, had excellent scholastic execution at schools. Parents with great interest in education can communicate effectively with their children's regarding the teaching, homework, and practices taught at schools. Parents with a positive and realistic view of their capacity tend to take advantage of social support and a high priority for their children for the success of children at school (Henderson 1994).

Children from single parents also have equally great achievements from children who have complete parents. However, single parents are expected to develop a social support network. It implies that couples' parents can use their experience to help children, while single parents must be harder in developing their confidence and support networks. Jeynes (2002) found that the effects of divorce or death of parents affect children's academic achievement in school and even families who divorce and experience poverty. In addition, schools can have full strength in building parental capacity, such as secure communication between home and school, strengthening social support for parents, and staff can provide information for parents to strengthen what happens at school.

\section{Conclusion}

The study conducted to know the barriers in academic achievement at secondary schools in district Jafarabad, Balochistan. The universe of the study was four central union councils, i.e. UC Sobdarani, UC Gandakha, UC Nushki Jadeed and UC Shahan Palay of Tehsil Gandakha district Jafarabad while the targeted population was parents of those children who enrolled in 10th class at six secondary 
schools. The respondents of the study selected through a simple random sampling technique. The results of the study concluded that most of the respondents were residing in rural areas of district Jafarabad. Further, it shows that little more than half of the respondents' children secured satisfactory academic achievement in the 9th class. Most of the parents were satisfied only to some extent, with access to secondary school education to middle-class families. The study revealed that the majority of the parents were not aware of the importance of education and were academically illiterate. Parental participation in school parent-meetings remains very low as most of the parents never pay a visit to the schools where their children were enrolled. The parental emotional support also found very low, and parents do not reward their children and do not monitor their children's classwork.

Academic achievement based on parental awareness about the importance of secondary education for a better future of their children and assistance to their children in educational problems faced at schools and home. Education Department of Balochistan and local non-governmental organisations should run campaigns on the importance of education generally and specifically academic achievement at the secondary level of schooling and future career planning in district Jafarabad. At the community level, the local government bodies and civil society should be active in persuading the community members to assist their children in school problems and the importance of education. Parents shall create a conducive venue for improving the learning process in such a way that self-confidence among these children is enhanced.

\section{References}

American Federation of Teachers (2000) Building a profession: Strengthening teacher preparation and induction (Report of the K-12 Teacher Education Task Force). Washington DC: Author.

Aman J, Akram MB, \& Saud M (2018) Socio-political unrest in Pakistan: A perception of university students in the Province of Balochistan, Pakistan. Matra Pembaruan: Jurnal Inovasi Kebijakan, 2 (2):97-109. https://doi.org/10.21787/mp.2.2.2018.97-109.

Baloch S (2015) The Bleak Future of Education in Balochistan. www.tribune.com.pk/story/825557/ the-bleak-future-of-education-in-balochistan/on 22/01/2015.

Considine G \& Zappala G (2002) The influence of social and economic disadvantage in the academic performance of school students in Australia. Journal of Sociology 38 (2):129-148. https:// doi.org/10.1177/144078302128756543.

Davies D (1988) Helping Parents Help Their Kids. Arlington, VA: National School Public Relations Associations.

Davies L \& Iqbal A (1997) Tension in Teacher Training for School Effectiveness: The Case of Pakistan, School Effectiveness and School Improvement, 8(2), 254-266. https://doi. org/10.1080/0924345970080205.

Eagle E (1989) Socioeconomic Status, Family Structure, and Parental Involvement: The Correlates of Achievement. A Paper Prepared for The American Education Research Association, San Fransisco: March 30, 1989.

Eccles JS (2005) Influences of parents' education on their children's educational attainments: The role of parent and child perceptions. London Review of Education 3 (3):191-204. DOI: 10.1080/14748460500372309.

Fitriani N, Aymen M, ul Huda N, Tufail SM, Amir S, \& Saud M (2019) Gender perceptions and adaptation strategies to climatic hazards-floods in rural areas of District Sialkot, Punjab, Pakistan. IOP Conference Series: Earth and Environmental Science 245(1):012028. IOP Publishing.

Haider SZ (2008) Challenges in higher education: Special reference to Pakistan and South Asian developing countries. Nonpartisan Education Review 4 (2).

Henderson AT \& Berla N (1994) A New Generation of Evidence. Virginia USA: National Committee for Citizens in Education. 
Jeynes WH (2002). Examining the effects of parental absence on the academic achievement of adolescents: The challenge of controlling for family income. Journal of Family and Economic Issues 23 (2). https://doi.org/10.1023/A:1015790701554.

Khalid SM \& Khan MF (2006) Pakistan: The state of education. The Muslim World 96 (2):305-322. https://doi.org/10.1111/j.1478-1913.2006.00130.x.

Khan RM \& Zubairi N (1999) Parental Involvement and reading Attainment: A Study of 4th Grade Pakistani Children. Journal Pendidikan 20:83-94. Fakulti Pendidikan University, Malaya.

Krashen S (2005) The hard work hypothesis: Is doing your homework enough to overcome the effects of poverty? Multicultural Education 12 (4):16-19.

Lippman LB \& McArthur E (1996) Urban Schools: The Challenge of Location and Poverty. Executive summary. (U.S. Department of Education, National Center for Education Statistics Rep. No. NCES 96-864). Washington DC: U.S. Government Printing Office.

Llyoid CB, Mete C, \& Grant MJC (2009) The implications of changing educational and family circumstances for children's grade progression in rural Pakistan: 1997-2004. Economics of Education Review 28:152-160.

Lynd D (2007) The Education in Pakistan: Assessment of The National Education Census. Islamabad: UNESCO.

Marzano RJ (2003) What Works in Schools: Translating Research Into Action?. http://pdonline.ascd. org/pd_online/whatworks/marzano2003_ch13.html.

Memon GR (2007) Education in Pakistan: The key to issues, problems and the new challenges. Journal of Management and Social Sciences 3 (1):47-55.

Okpala CO \& Smith FE (2001) Parental involvement, instruction expenditures, family socioeconomic attributes, and student achievement. The Journal of Educational Research 95 (2):110-115. https://doi.org/10.1080/00220670109596579.

Psacharopoulos G (1994) Returns to Investment in Education: A Global Update. World Development 22 (9):1.325-1.343.

Repetti RL (1996) The effects of perceived daily social and academic failure experiences on schoolage children's subsequent interactions with parents. Child Development 67 (4):1467-1482.

Titus MA (2006) Understanding college degree completion of students with low socioeconomic status: The influence of the institutional financial context. Research in Higher Education 47 (4):371-398.

Trotman MF (2014) Involving the African American parent: Recommendations to increase the level of parent involvement within African American families. Journal of Negro Education 70 (4):275-285.

Walpole M (2003) Socioeconomic status and college: How SES affects college experiences and outcomes. The Review of Higher Education 27 (1):45-73.

Wang MC, Haertel GD, \& Walberg HJ (1990) What influences learning? A content analysis of review literature. The Journal of Educational Research 84 (1):30-43. https://psycnet.apa.org/doi/10 $.1080 / 00220671.1990 .10885988$.

Westbrook J, Shah N, Durrani N, Tikly C, Khan W, \& Dunne M (2009) Becoming a teacher: Transitions from training to the classroom in the NWFP, Pakistan. International Journal of Educational Development 29:437-444. https://doi.org/10.1016/j.ijedudev.2008.12.001.

Zafar M (2003) "Fiscal Devolution in Education". Case study Reflecting Initial Responses. Ministry of Education, Islamabad, Pakistan, pp.34-41. 